IBAD, 2020; (8): 115-128

\title{
Yeni Sosyal İlişki Düzeninin 15. İstanbul Bienali Üzerinden Okunması
}

\section{Dr. Öğr. Üyesi Caner Şengünalp ${ }^{1 *}$}

Gelis tarihi: 20.04.2020

Kabul tarihi: 29.04 .2020

\section{At tf bilgisi: \\ IBAD Sosyal Bilimler Dergisi \\ Sayı: $8 \quad$ Sayfa: $115-128$ \\ Yıl: 2020 Dönem: Güz}

This article was checked by Turnitin. Bu makalede araştırma ve yayın etiğine uyulmuştur.

${ }^{1}$ Atatürk Üniversitesi, Türkiye, canersengunalp@atauni.edu.tr, ORCID ID 0000-0002-7167-9167

\footnotetext{
* Sorumlu yazar
}

ÖZ

Bu araştırmanın amacı, sosyal bir ilişki ağı olan komșuluk kavramının sahip olduğu sosyo kültürel, günlük yaşam, tarihsel ve siyasi dinamikleri üzerinden kurulan etkileșimleri bir güncel sanat etkinliği aracılığıyla aktararak, bir arada yaşayabilmenin önemini alternatif bir ifade biçimi üzerinden hatırlatmaktır. Bienal, iki yılda bir yapılan, farklı kültürlerden ve ülkelerden sanatçı, eser, izleyici ve eleştirmenleri bir araya getiren küresel bir sanat etkinliğidir. 16 Eylül-12 Aralık 2017 tarihleri arasında izleyiciyle buluşan 15. İstanbul Bienali'nin ana teması iyi bir komşu idi. Bu başlık altında gerçekleşen bienali ortaya çıkarabilmek, sanatçılarına kimliklerinden feragat etmeden bir arada yaşamak zorunda olduklarını hatırlatmıştır. Peki, iyi bir komșu nedir? Bunun tek bir tanımı yoktur. İçinde bulunduğumuz zamana, mekâna ve topluma göre farklılıklar gösteren komşuluk, ev, mahalle, şehir, ülke ve evren gibi farklı ölçeklerde yaşanabilen sosyal bir ilișki düzenine sahiptir. Serginin küratörleri Elmgreen ve Dragset, İyi bir komşu, korkmadığınız bir yabancı mıdır?, Lyi bir komşu sizinle aynı gazeteyi mi okur? gibi komşuluk kavramı etrafinda oluşturdukları 40 soruyla bienalin kavramsal çerçevesini belirlerken, dikkatleri barınak ve tasarım olarak ev fikrinden uzaklaştırıp yan yana yaşayanlara çekmişler ve sanatçılar bunun üzerinden çalışmalar üretmişlerdir. 32 ülkeden 56 sanatçının 6 mekânda seyirciye sunulan 150 eseri, farklı grup, kimlikler ve sosyal statüler bağlamında iyi bir komşunun kim olduğunun ölçütlerini sorgulamıștır. Dünya insanı olmakla iyi bir komşu olma arasındaki anlam benzeşmesine kadar bizleri sorgulatan bienalden biz payımıza düşeni aldık mı? Bu araştırmada, serginin ana teması olan komşuluk ve onun farklı tanımları üzerine yapılan çalışmalar arasından belirlenen seçili örnekler analiz edilmiş, yapıtların çağdaş sanat ortamına kattığı yeni çağrıșımlar görünür kılınmıs, birbiriyle bitișik ve yan yana olma halinin sanat aracılığıyla nasıl bir sorgulama zeminine çekildiğini göstermek hedeflenmiştir. İçinde bulunduğumuz dönemde covid-19 salgını nedeniyle insanların toplu olarak bir arada bulunmalarının kısıtlandığı, toplum sağlığı gözetilerek evde kalma süreçlerine girdiği bu süreçte sosyal ilişkilerin önemi bir kez daha anlaşılmış, İyi Bir Komşu Sergisi'ne bu perspektiften bakıldığında anlam alanı daha da genişlemiştir.

Anahtar Kelimeler: 15. İstanbul bienali, iyi bir komșu, sosyal ilișki, güncel sanat 


\title{
Reading the New Social Relationship Order on the 15th Istanbul Biennial
}

\author{
Assist. Prof. Dr. Caner Sengunalp ${ }^{1^{*}}$
}

First received: 20.04 .2020

Accepted: 29.04 .2020

\section{Citation:}

IBAD Journal of Social Sciences

Issue: $8 \quad$ Pages: 115-128

Year: $2020 \quad$ Session: Fall

This article was checked by Turnitin.

\author{
${ }^{1}$ Ataturk University, Turkey, \\ canersengunalp@atauni.edu.tr,
} ORCID ID 0000-0002-7167-9167

\section{* Corresponding Author}

\begin{abstract}
The aim of this research is to remind the importance of being able to live together by transferring the interactions based on the socio-cultural, daily life, historical and political dynamics of the concept of neighborhood, which is a social relationship network, through an alternative form of expression. The biennial is a global art event that brings artists, works, viewers and critics from different cultures and countries at two-year intervals. The main theme of the 15th Istanbul Biennial, which met the audience between September 16 and December 12, 2017, was a good neighbor. Being able to reveal the biennial under this title reminded their artists that they had to live together without sacrificing their identities. So what is a good neighbor? There is no single definition for this. The neighborhood, which varies according to time, place and society, has a social relationship order that can be lived in different scales such as home, neighborhood, city, country and universe. The curators of the exhibition, Elmgreen and Dragset, Are you a good neighbor, a stranger you are not afraid of, Is a good neighbor reading the same newspaper as you? While determining the meaning area of the biennial with 40 questions they created around the concept of neighborhood, such as shelter and design, they drew attention from the idea of home and drew side by side, and the artists produced works based on it. 150 works of 56 artists from 32 countries presented to the audience in 6 venues have questioned the criteria of who a good neighbor is in the context of different groups, identities and social statuses. Did we take our share from the Biennial, which questioned us until the meaning between being a human being of the world and being a good neighbor? In this study, selected examples determined among the studies on neighborhood, which is the main theme of the exhibition and its different definitions, were analyzed, and the new connotations that the works add to the contemporary art environment were made visible, and it was aimed to show how the state of being adjacent and side by side was drawn to the ground of inquiry through art. The importance of social relations was once again understood in this process, in which people were restricted to coexist due to the covid-19 outbreak in the current period, and entered the processes of staying at home considering the public health.
\end{abstract}

Keywords: 15th Istanbul biennial, a good neighbor, social relations, contemporary art 


\section{GİRIŞ}

Bienal, iki yılda bir anlamına gelmektedir. Sanat alanının küresel merkezine oturmuş durumda olan bienal, tek başına telaffuz edildiğinde dahi sanatsal ipuçları veren bir anlam ifade etmektedir. Hazırlanış sürecinin uzunluğundan ve maddi gereksinimlerin yüksek olmasından dolayı iki yılda bir düzenlenen bienaller, gösteri toplumunun sanat alanındaki uzantılarıdır. "Bienaller genellikle bir küratör öncülügünde yapılan, belirli bir konu etrafında örgütlenen sanat olayıdır” (Ersöz, 2009, s. 26). Uluslararası küratörlerden biri olan Rosa Martinez bir bieanali meydana getiren şey nedir? sorusuna şöyle yanıt arıyor: "İdeal bir bienal özünde politik ve ruhani bir şeydir. Bugünü tefekkürle izlerken onu değiştirmektir arzusu. Arthur Danto'nun hayran olduğum tanımlamasındaki gibi, bienal, ulus aşırı bir ütopyanın bir anlık görünümüdür"(Stallabrass, 2016, s. 41).

İlk olarak Venedik'te 1895 yılında gerçekleşen Venedik Bienali, zamanla uluslararası platformda düzenlenmeye başlanmıştır. Giderek büyüyen Venedik Bienali dünyanın en önemli sanat olaylarından biri konumuna gelmiştir. Venedik Bienali ile başlayan uluslararası bienallerin amacı; sanatçıların eserlerinin dünya sanat ortamına tanıtılması, ülkenin kültür turizmi açısından yerini sağlamlaştırmak, çağdaş sanatta söz sahibi olmak isteyen sanatçıları bienallere dâhil ederek kültür sanat etkileşiminin içinde katmaktır. Bienallerin uluslararası olması farklı ülkelerde yapılan sanat üretimlerinin sadece sanatseverler ve koleksiyonerler tarafından değil aynı zamanda her kesimden izleyici tarafindan da gözlemlenebilmesi ve karşılaştırılması olanağını sunmaktadır. Dünya'da sanat küreselleşme ve organizasyonlaşma konusunda bu denli erken bir süreçte adım atarken, Türkiye'de bu anlamda ilk hareketlenme 70'li yıllarda olmuş, İstanbul Kültür ve Sanat Vakfı'nın öncülüğünde devlet dış1 oluşumlar, kültür-sanat mecrasında özellikle İstanbul'un dünyayla temasının yolunu açmışlardır. "Türk sanatı yüzyıllardır tarih içerisinde, toplumun kültürel yapısına uygun olarak, değişim ve gelişim göstererek varlığını sürdürmüştür. Ülkemizde görsel sanatların varlık göstermeye başladığı dönemlerden itibaren sanatçılar, sanatı yaymak ve sanatçıyı korumak, kendilerini ve sanatlarını geliştirip, sunmak amacıyla, belli etkinlikler çerçevesinde sanatlarını topluma tanıtma firsatı bulmuşlardır. Böylece hem yurt içi hem de yurt dışındaki plastik sanat dallarını uluslararası bir ortamda sunarak, bir kültür ağının oluşmasını sağlayan pek çok sanatsal faaliyetler düzenlenmeye başlamıştır. Bu faaliyetlerin en önemlilerinden biri de Uluslararası İstanbul Bienalidir"(Okur, Bozdoğan, 2017, s. 3307). 1980 darbesi sonrası Türkiye'nin içinde bulunduğu sosyo politik ortam, bir takım baskı ve sansürlerin doğmasına neden olmuş, bu durum "ekonomik liberalleşmenin sınırsız tüketim vaadi arasına sıkışmış olan İstanbul'da festivaller, kültürel mekân ve kimliklerin yeniden kurulmasında önemli rol oynamışlardır"(Yardımc1, 2014, s. 8). Festivaller bu dönemde sermaye ve kent elitlerinin küreselleşme hevesi ile kenti dünya kamuoyuna pazarlama araçlarından biridir. İstanbul Bienali de İstanbul'u bir dünya kültür başkenti yapma arzusuyla popülerleştirilen bu festivallerin bir parçasıdır. İstanbul Kültür ve Sanat Vakfı tarafından organize edilen ve ilk olarak 25 Eylül-15 Kasım 1987 tarihleri arasında düzenlenmiş olan 1. Uluslararası İstanbul Çağdaş Sanat Sergileri, Geleneksel Yapılarda Çağdaş Sanat başlığında ve Beral Madra koordinatörlügünde yapılmıştır. Günümüze kadar gelerek sürekliliğini koruyan ve otuz yılı aşkın bir süredir var olan Uluslararası İstanbul Bienali, ülkemizde plastik sanatların ve görsel sanatların gelişmesi açısından büyük bir önem taşımaktadır. Uluslararası İstanbul Bienallerinin her biri kendi içerisinde kavramsal çerçevesi, sanatçıları, küratörü, seçici kurulu, mekânları ile farklı özelliklere ve kriterlere sahip olmuştur. Kültürler arası etkileşimi sağlayan, yerel sanat ortamını evrensel boyuta taşıyarak bir ilişki ve iletişim alışverişine zemin hazırlayan İstanbul Bienali, sanatı alışılmış sergi mekânlarından dışarı taşmasını sağlarken, çağdaş sanatın güncel örneklerini Türkiye sanat ortamıyla buluşturarak iki yılda bir güncellenmesine katkıda bulunmaya devam etmektedir.

\section{5. İSTANBUL BİENALI “İYİ BİR KOMŞU” SERGİSI}

Şehir yaşamının komşuluk ilişkilerini yok ettiği, giderek yalnızlaşan hayatların içinde yaşam biçimlerinin yapısal kodlarının değiştiği bir ortamda 15. İstanbul Bienali İyi Bir Komşu teması ile ev, aidiyet, yerellik, ortak yaşam, mahalle ve göç kavramlarıyla bu gidişata dikkat çekmek istemiştir. Otuzuncu yılında, 1995 yılından beri birlikte yaşayan İskandinav sanatçı ikilisi Michael Elmgreen ve Ingar Dragset küratörlüğünde 16 Eylül-12 Aralık 2017 tarihleri arasında gerçekleşen bienal, İstanbul Modern, Galata Özel Rum İlköğretim Okulu, Pera Müzesi, Küçük Mustafa Paşa Hamamı gibi 
birbirine komşu mekânların yanı sıra Ark Kültür ile Yoğunluk Sanatçı Atölyesi'nde de sergilenerek izleyiciye mahalle olgusunu deneyimletmeyi hedeflemiştir. Daha önceki bienaller İstanbul'un çeşitli bölgelerine yayılarak şehirde küçük bir gezinti yapıp, şehrin belleğini izleyicinin belleğinde imgelemeyi amaçlarken, 15. İstanbul Bienali'nin anlamsal altyapısının komşuculuk kavramı çerçevesinde kurgulanması, bienalin mekânsal ölçeğini de belirlemiş, sergileme alanları daha çok küçük mahalleler seviyesinde tutulmuştur.

Mekânların her biri farklı türde toplumsal kurumu temsil ederken, sergi alanlarının Beyoğlu'nda olmasının da altında yatan sebep; Beyoğlu'nun kaybettiği kentsel kimliğini sınırlı bir süre için de olsa geri kazandırmaktır. Mekânsal bağlamda kurulan yakın komşuluk bağının yanında uzak komşuluk meselesi de dikkate değer bir konudur. "Çünkü bu komşuluklar, politik ve kültürel meselelerin görünür kılınması ve farkındalık yaratılması açısından önemlidir. Böylece uluslararası alandan sanatçıların bienal gibi bir etkinliğe davet edilmesiyle, diğer bir deyişle komşuların çağrılmasıyla, bu etkinlikte, sınırlar, jeopolitik meseleler, savaş ve kıtlık nedeniyle yerinden edilmiş nüfuslar ya da problemlere dair geçmişten/güncelden konuların ele alındığı görülebiliyordu" (Arapoğlu, 2017, s. 70).

"15. Uluslararası İstanbul Bienali, Türkiye'nin Avrupa Birliği ve ABD ile gerilen ilişkileri, Suriye'deki iç savaş ve Irak'taki politik konjonktürdeki pozisyonu, 15 Temmuz Darbe Girişimi gibi birçok aktüel politik gelişmenin gölgesinde gerçekleştirildi” (Arapoğlu, 2017, s. 70). Son y1llarda küresel ölçekte yaşanan terör olaylarına paralel, ulusal anlamda Türkiye'de de toplumsal yaşamı olumsuz etkilemiş olan saldırılar, yaşanan darbe girişimi ve sonrasında yaşanan süreç, her alanda olduğu gibi kültür sanat ortamını da olumsuz etkilemiş̧tir. Birçok etkinliğin ertelendiği ya da iptal edildiği bu çalkantılı dönemde sanat üretmenin, düşünmenin, konuşmanın önemine varılmış, sanatın bir tür problem giderme ve nefes alma platformu olarak kullanılması amaçlanmıştır. Sergi takvimi olarak bu sürecin içine hem fiziksel hem de zihinsel kodlarla dâhil olan 15. İstanbul Bienali, "toplumsal travmalar ve siyasi depremlerin gelecekle ilgili endişeleri tepe noktasına ulaştırdığı ve bireysel özgürlüklerin köşeye sıkıştı̆̆ bir dönemde kişisel hikâyelerin peşinden gitti’(Örer, 2017, s.18).

Bige Örer'in direktörlüğündeki bienalin sanatçıları, iyi bir mahalleyi ve yuvayı oluşturan nitelik ve davranışları araştıran kırk soruluk afişler hazırladılar (Görsel 1). Bienaldeki 56 sanatçı da bu sorulara cevap vermek yerine tekrar tekrar, dikkatlice, cesaretle ve bazen kaygiyla bu soruları sormanın daha şaşırtıcı yollarını buldu(Wilson, 2017, s. 55). Iyi bir komşu korkmadığınız bir yabancı mıdır? , Iyi bir komşu daha yeni taşınmış birisi midir? , Iyi bir komşu sizinle aynı gazeteyi mi okur? gibi soruları barındıran bu afişler şehrin sokaklarına, mahallelerine, dükkânlara, kafelere, otobüs duraklarından evlerin camlarına (Görsel 2) kadar tüm şehre yayılarak, insan olmakla iyi bir komşu olma arasındaki anlam benzeşmesine kadar izleyiciyi bir sorgulama sürecine dâhil etmiştir. 


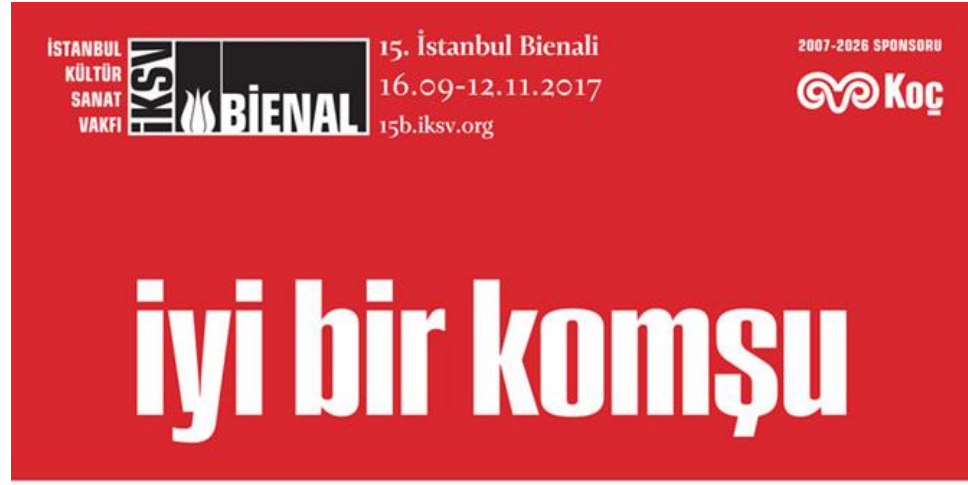

\section{siz hastayken}

size yemek

\section{yapar mi?}

- $\sigma /$ istanbulbienali

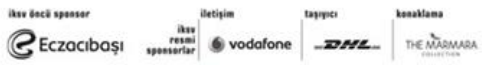

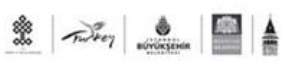

Görsel 1. 15. İstanbul Bienali Tanıtım Afişi, 2017

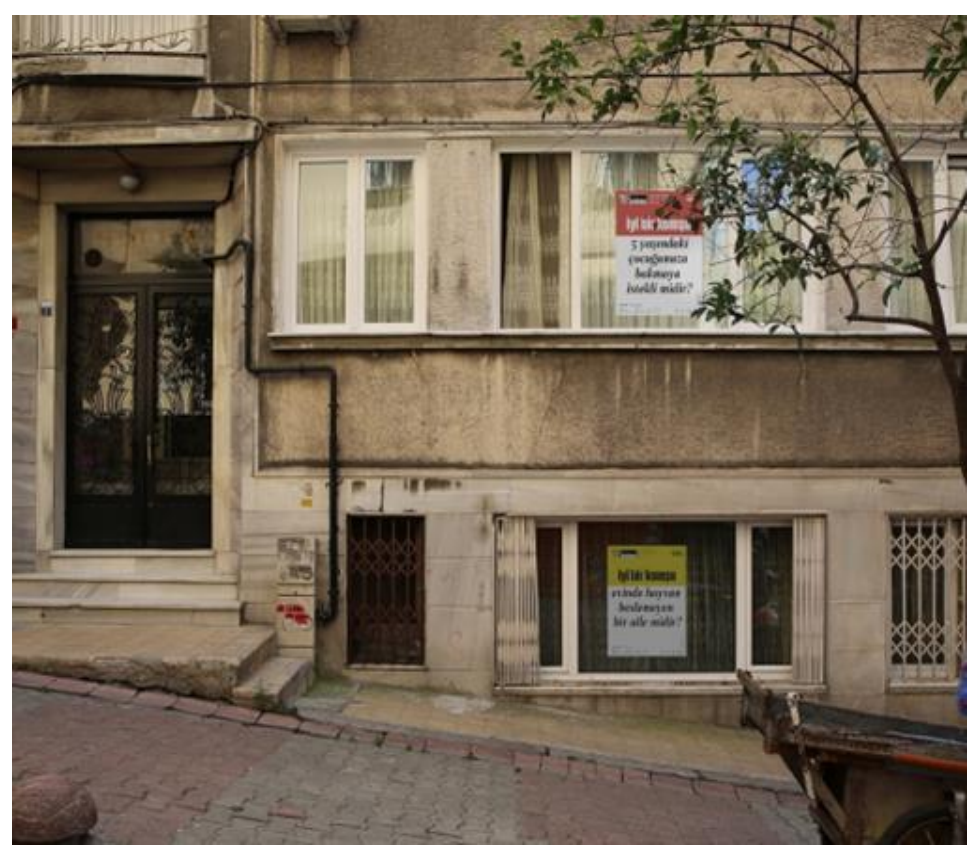

Görsel 2. 15. İstanbul Bienali Tanıtım Afişi, 2017 
Fransız filozof Gaston Bachelard'e göre en farklı kuramsal ufuklar çerçevesinde incelendiğinde ev imgesi, öz varlığımızın topoğrafyasına dönüşmektedir (Bachelard, 1996). Ev ile ruhsal bir bağıntı kuran Bachelard, evin temelden çatısına dek ilerleyen inşasıyla ruhun kademe kademe katmanlaşmasını aynı sürecin iki dinamiği olarak görmüş, evi insan ruhunun çözümleme aracı olarak tanımlamıştır. Ona göre "evimiz bizim dünya köșemizdir. Bizim, sık sık yinelendiği gibi, ilk evrenimizdir. Ev, gerçek bir kozmostur" (Bachelard, 1996, s. 32). Serginin küratörleri Elmgreen ve Dragset de, ev ve komşu terimleri arasında sürekli gidip geldiklerini ifade etmişler, bienale ilişskin hedeflerini şu sözlerle açıklamışlardır; "15. İstanbul Bienali, son yirmi-otuz yıldır eve dair algımızın nasıl değiştiğini, ev ortamlarımızda kimliklerimizi nasıl koruduğumuzu, sakındığımızı ve ifade ettiğimizi araştırmakla birlikte, bu özel alanların, evlerimizin yan yana nasıl işlediğini de görmeye çalışıyor. Sergi için iyi bir komşu başlığını seçerken, dikkatleri barınak ve tasarım olarak ev fikrinden uzaklaştırıp yan yana yaşayanlara çekmek istedik" (Elmgreen ve Dragset, 2017, s. 31).

Yan yana yaşama fikri, yeni yaşam ve paylaşım mekânlarına bir köprü atarken, bu kurulan bağ ister istemez bir müşterekleşme pratiğini de doğurmaktadır. Mimar, aktivist ve akademisyen Stavros Stavrides'e göre "müşterekleşme pratikleri insanlar arasında yeni ilişkiler üretiyor. Paylaşma biçimlerinin örgütlenmesini ve ortak yaşamın vücuda gelmesini mümkün kılan yaratıcı karşılaşmaları ve müzakereleri teşvik ediyor. $\mathrm{O}$ halde, müşterekleşme pratikleri sadece malları üretmekle ve dağıtmakla sınırlı kalmıyor; en temelde yeni toplumsal yaşam biçimleri, müşterekte yaşama biçimleri yaratıyor. İşte bu yüzden, müşterekleşme pratikleri, müşterekte yaşamanın olası biçimlerine işaret etmesi açısından tasarımsal, müşterekleşme süreçlerine katılanların paylaştı̆̆ değerlere dikkat çekmesi açısından dışavurumcu ve egemen toplumsallık modellerinin dayattığı sınırları aşan toplumsal ilişkileri kısmen kurması bakımından ilham verici olabilir" (Stavrides, 2018, s.16). Bu eksende herkes kendini de bir komşu olarak görmekle başlayabilir, nasıl daha iyi bir komşu olabileceğini sorgulayabilir, diğer insanlarla olan farklılıklarını kabul ederek yan yana yaşama pratiklerini geliştirebilir. Amerikalı yazar Nancy L. Rosenblum'un belirttiği gibi: "Kendi üzerimize düşünmenin gereçlerine hayal gücümüzü kullanarak araştırma, sabır ya da sağduyu her zaman sahip olamayabiliriz. Kendimizle uğraşmayız. Komşular bu ilgisizlik perdesini yırtabilir, bizi kendi işimizle meşgul olmaya itebilir" (Rosenblum, 2016, s. 233). Rosenblum'un burada kendi işimizle meşgul olmak derken, başkalarının meşguliyetinden uzak durmayı değil, diğer insanların yaşamı ışı̆̆ında insanın kendiyle gerçekten meşgul olabilmesini kastetmektedir.

Kimlik, yaşam tarzları, aidiyet, kamu ile özel arasındaki ayrıma ilişkin meseleler, çağdaş sanatta uzun zamandır üzerine gidilen, araştırma yürütülen ve çalışma yapılan önemli üst başlıklardır. Bu bağlamda bienalin küratöryel sürecinde önemli referanslar sunan bu meseleler özelinde ev ve aidiyet, alabildiğine çok katmanlı bir tema olarak öne çıkmış, herkesi ilgilendiren, kendi kişisel deneyimlerinden yola çıkarak üzerine konuşabileceği bir konu olması bakımından serginin temeline oturmuştur. Bienalin organize edildiği süreçte pek çok coğrafyada bir çatışma iklimi hüküm sürmesi bakımından etkinliğin izleyici üzerinde daha derin etkiler bırakması kaçınılmaz olurken, günümüzde içinde bulunulan covid-19 salgın sürecinin yarattığı yeni toplumsal normlar ve sosyal ilişkiler ağıyla da taban tabana örtüşmesi, serginin güncelliğini halen koruduğunu göstermektedir.

Bienal boyunca sanatçı Zeyno Pekünlü koordine ettiği 15. İstanbul Bienali Kamusal Programı kapsamında Seçilmiş Aileler ve Müşterek Kader adı altında atölye ve sempozyumlar gerçekleştirilmiştir. Okuma grubu, Ezgi Tuncer ile yemek, Evrim Hikmet Öğüt ile müzik atölyesi ve Hamisch İstanbul Suriye Kültür Evi'nin de parçası olduğu çocuklar için animasyon ve karakter tasarımı atölyesi gibi birçok farklı etkinlikler düzenlenmiştir. Bunların dışında, 26 farklı yazar bienal boyunca T24 te iyi bir komşu üzerine yazılar yazmış ve T24'teki yazı dizisiyle farklı alanlardan insanların konuya yaklaşımı tartışmaya açılmıştır.

Küratörlerinin sanatçılar arasından belirlenmesiyle dikkat çeken bu bienalde, farklı ülkelerden sanatçıların, video art, resim, seramik, enstalasyon, heykel gibi 150 adet çalışma bulunmaktadır. $\mathrm{Bu}$ çalışmalar arasından serginin bağlamına en uygun çalışmalar arasından seçilen örnekler analiz edilerek konu temellendirilecektir.

Belçikalı çağdaş sanatçı Berlide De Bruyckere battaniyeleri heykellerinde uzun süredir kullanmaktadır. Öncelikle 1sınmak için kullanılan battaniyeler aynı zamanda kendini gizleme ve 
saklanma aracı olarak da kullanılabilir. Sanatçının 1999 yılında ürettiği Konuşmak adlı yapıtı (Görsel 3) tam da bu bağlantıyı daha öteye taşıyarak insanlar arası iletişim, gizlilik ve birleşme, yakınlık ve konuşmanın dopdolu ve yoğun bir alegorisine dönüştürüyor. Çalışmada birbirine dönük olan iki figürün üzerini 1sınma, gizlenme ve saklanma arac1 olan bir battaniye ile örterek insanlar aras1 iletişime, gizlilik ve birleşmeye dikkat çekiyor. Bu figürlerin iletişim kurup kurmadıklarını belirsiz bırakan yapıt sanki şunu soruyor gibi: İki insan gerçekten anlamlı bir şekilde birbiriyle konuşabilir mi? Birbirini anlamak mümkün müdür? Kim, kimin adına ve kime konuşabilir? Aslında yapıt, günümüz dünyasının güncel sorularını da akla getiriyor. İnsanlar arası iletişim gittikçe daha az görünür ve kamuya daha az açık özel bir iletişim haline mi geliyor? Yoksa bu heykeller, özgürce konuşabilecekleri tek özel alanları olduğu için mi kendilerine böyle bir kaçak bir 'ev' kurmuşlar? O zaman yakınlık ve birbirini anlama bir geri çekilme anlamına $\mathrm{m}$ gelmelidir? Bu heykel, konuşma özgürlüğünün tehdit altında olduğunu mu göstermektedir? Peki, öyleyse tehdit eden kimdir? $\mathrm{Bu}$ yapıtın sordurmak istediği nihai soru belki de şu olabilir: Yanlış iletişim ve yanlış anlama kaçınılmaz olsa bile, insanlar arasında yine de yakınlık doğabilir mi? (Lorios, 2017).

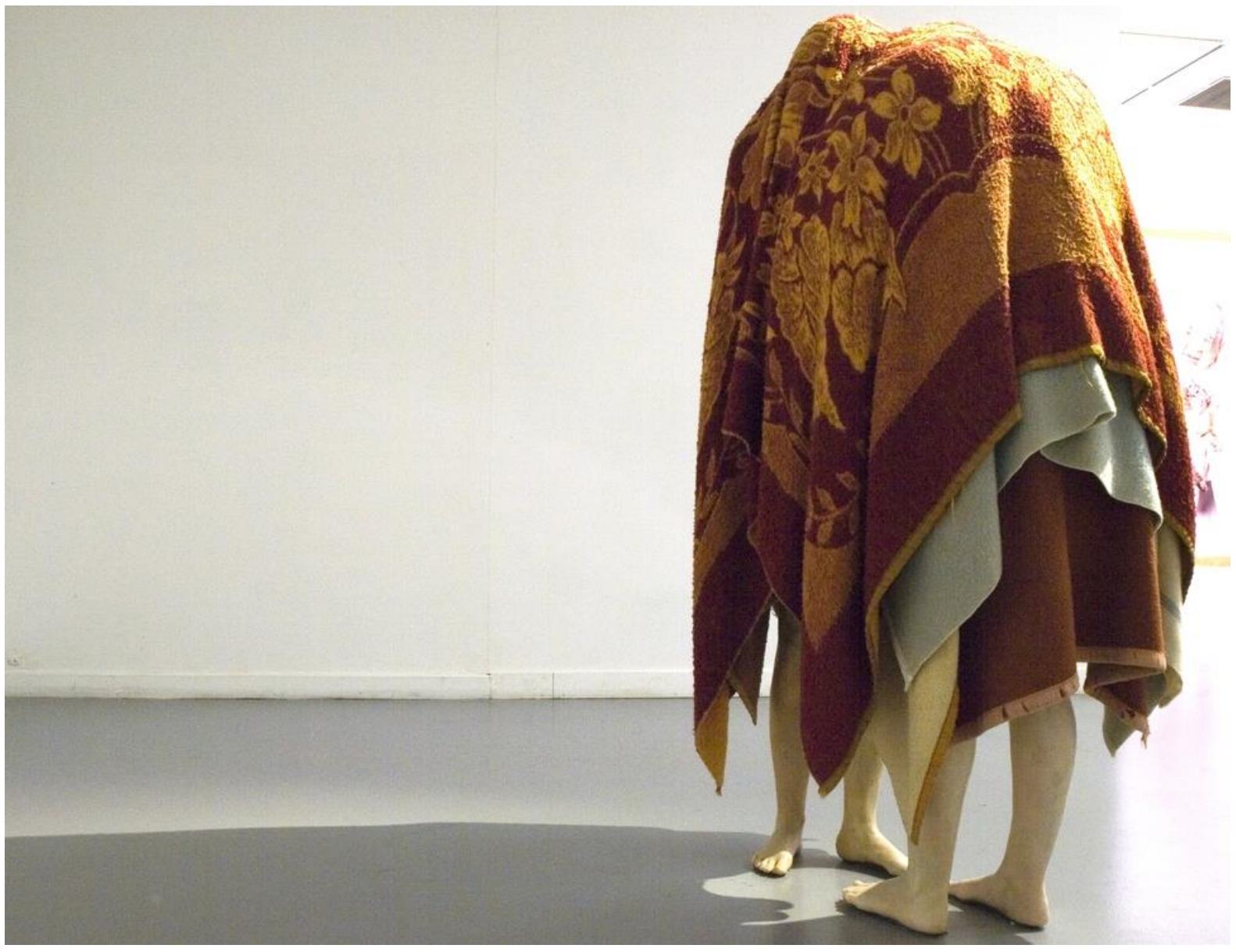

Görsel 3. Berlinde De Bruyckere, Konuşmak, 200x140x80 cm, Metal-Ahşap-Polyester-Battaniye,1999

Çoğu insan rüyasında tanıdığı bir evin bir anda ve anlaşılmaz bir biçimde henüz keşfedilmemiş bölmeler, odalar ve ek bölümlerle dolduğunu görmüştür. Evlerin içi huzur, özlem ve aidiyet duyguları bakımından neredeyse arketipleşmiş alanlardır; rüyalar kadar kâbuslara da konu olabilirler. Belli davranış senaryolarıyla hareket kalıplarının hâkim olduğu bu hayli duygusal mekânlar, korkularımızı ve isteklerimizi yansitır.

Leander Schönweger'in Galata Rum İlköğretim Okulu'nda sergilenen Ailemiz Kayboldu isimli projesi (Görsel 4), hem evlerin hem de kurum binalarının mimarisini, yakınlık ve yabancılaşma mefhumlarını düşsel bir tarzda ele alan bir enstalasyondur. Sanatçı bu enstalasyon için okulun çatısına bir labirent kurmuştur. İzleyiciler bir kapıdan girip başka bir kapısı olan bir odaya, sonra bu ikinci kapıdan yine öncekinin aynısı olan başka bir odaya gire gire ilerliyorlar. Ama birinden diğerine geçerken, odalar bir 
fraktaldaki gibi giderek küçülüyor. Labirentin içinde, tıpkı bir rüyada olabileceği gibi çoğalıp duran bu odalardaki duygusal yaşantılarını toparlayamaz ya da takip edemez bir halde, dışarı çıkmanın yolunu bulabileceklerinden belki de emin olmadan dolaşıp duran izleyiciler, kendileriyle iletişimleriyle beraber yön duygularını da yitiriyor ve kayboluyorlar. Ara sıra, henüz girmemiş oldukları yerlerden gelen tak tak sesleri bu deneyimi daha da yoğunlaştırıyor. Böylece odalar, insanları barındırma işlevlerinden giderek uzaklaşarak kendilerine ait bağımsız bir yaşama kavuşuyorlar. Labirentte kaybolmanın verdiği his, Yunan mitlerinden günümüz sinemasına kadar sanat ve kültürde önemli bir geçmişi olan bir motif, toplumsal dayanışma hissinin parçalanmasına, gelişmekte olan korumacılık, muhafazakârlık ve gelenekselcilik eğilimlerine kozmopolit yönelişin aksine, kendini yalıtma ve kopmayla tepki vermenin bir ifadesidir (Lorios, 2017).

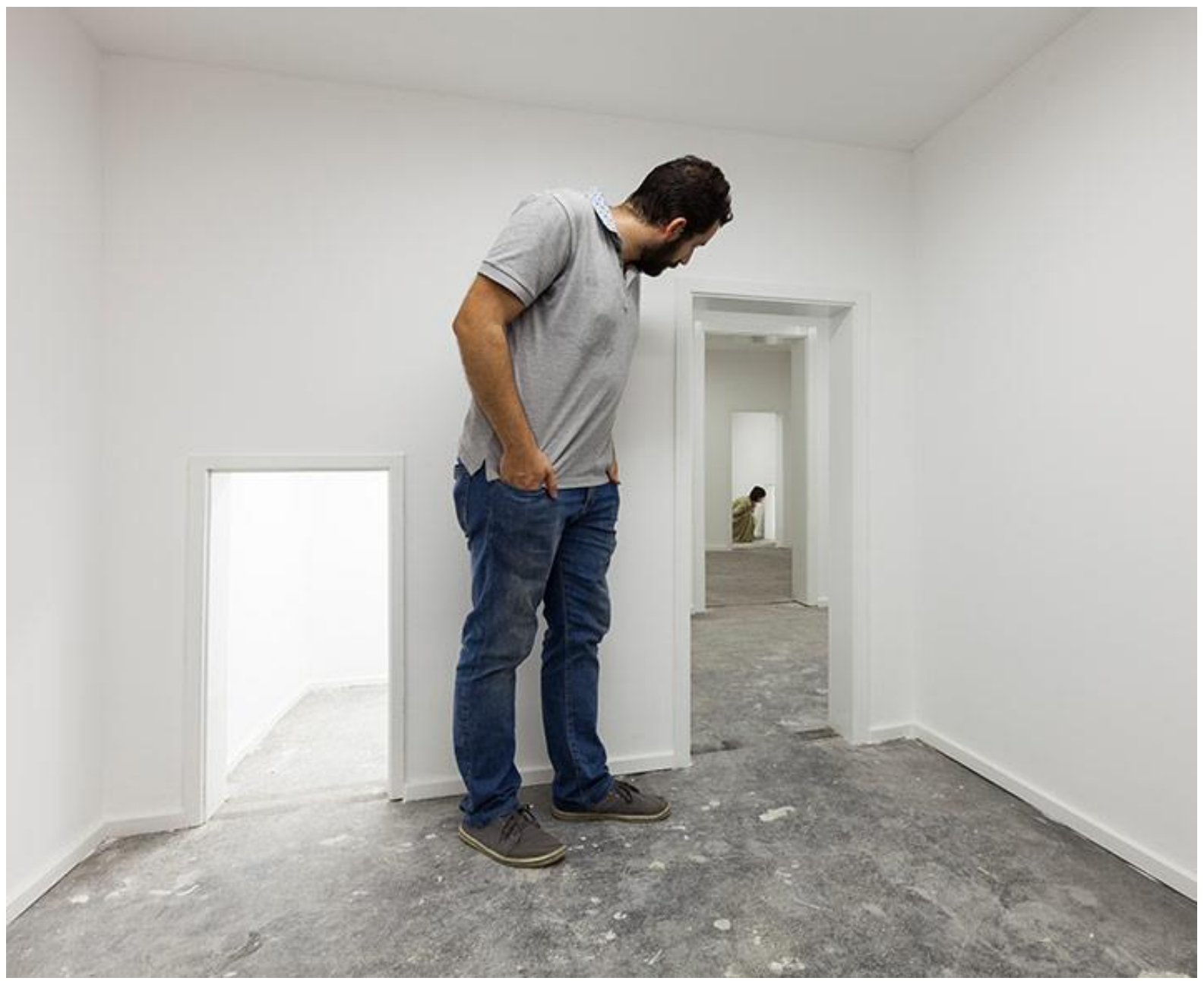

Görsel 4. Leander Schönweger, Ailemiz Kayboldu, Değişken boyutlar, Karışık teknik, 2017

Bir konutu ev yapan şey nedir? İki mekân özdeş görünebilirken aralarındaki fark içinde yaşanan, fiziksel olarak temas edilen evin hafizayı şifreleme ve sürdürme kapasitesinde yatıyor olabilir; alışkanlıklarla çoğalan kokular, örüntüler, duygular ve anılar. Temas ve koku duyularının hafıza ve duyguyla özellikle güçlü bir bağlantısı var; bir şey bizi duygusal olarak etkilediğinde ona dokunaklı diyoruz. Zaman içinde anılar kendi mimarilerini şekillendirebiliyor. Dan Stockholm, 2013'te babasını kaybetmesinin ardından temasın fizikselliği ile yas ve hafıza edimleri üzerine derinlemesine düşüncelerini ifade eden bir eylem başlattı ve bunun sonuçları sanatçının $E v$ adlı enstalasyonunda (Görsel 5) bir araya getirildi. Enstalasyon, Stockholm'ün üç gün boyunca babasının kırmızı tuğladan evinin tüm dış yüzeyine eliyle fiziksel olarak temas etme eyleminin dokümantasyonunu içeriyor. Son santimetrekareye de dokunduktan sonra Stockholm, ellerinin farklı jestler icra ederken bir dizi alçıdan kalıbını yapmaya başladı. $E v$, Stockholm'ün alçı kalıp ellerinin çelik çubuklar kullanılarak iliştirilmiş olduğu, payanda olarak da bilinen çelik yapı iskelesi sırıklarının ormanvari bir düzenlemesini içeriyor. Yapı iskelesi payandaları sadece konutu değil, hafızanın destekleyici yapılarını, hafızanın zaman ve 
uzaklık vasıtasıyla inşasını ve yeniden şekillendirilmesini de çağrıştırıyor. Stockholm’ün alçı kalıpları, sözcüklerle ifade edilmesi imkânsız yas edimini temsil eden sessiz jestler gibi, çeşitli pozisyonlardaki el ve parmakların kırmızı izlerini taşıyor (Lorios, 2017).

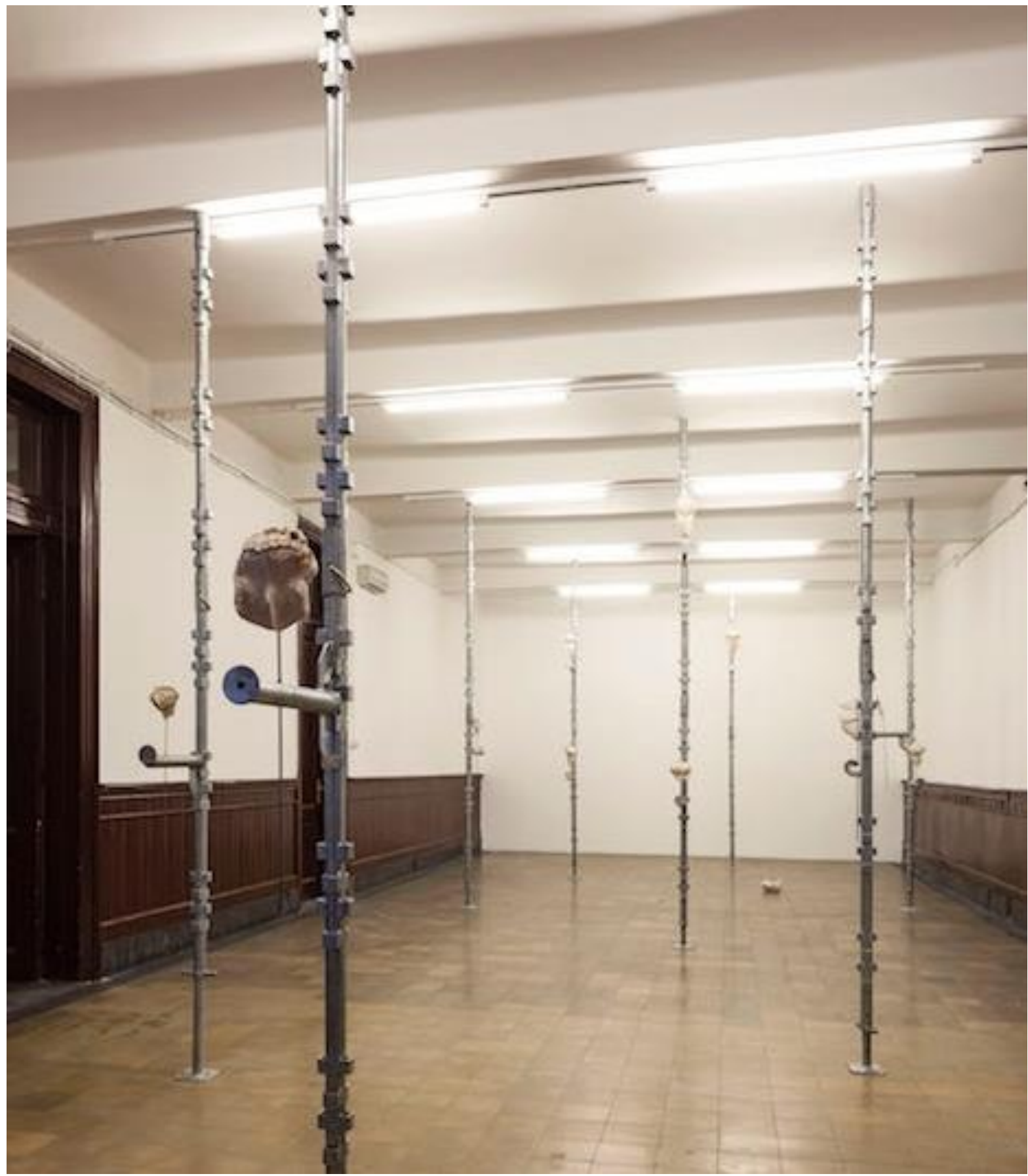

Görsel 5. Dan Stockholm, Ev, Değişken boyutlar, İskele-Alçı-Paslanmaz-Su-Epoksi-Video,2013-2016

Volkan Aslan'ın Evim Evim Güzel Evim başlıklı video enstalasyonu (Görsel 6), yerinden edilme gerçeklikleri üzerine derin bir düşünme niteliğindedir. Zaman ve perspektif ayrılıklarının, su ve yolculuk görüntülerinin kullanıldığı yapıt, göçmenler veya evini yitirmiş olanlar gibi uzun yolculuklara çıkmak zorunda bırakılan bireylere adanmış olduğu ifade edilmiştir. Evim Evim Güzel Evim, aynı zamanda, her birimiz farklı biçimde deneyimliyor olsak da aslında hepimizin aynı seyyar ve kırılgan insanlık koşulu içinde bulunduğumuzu anlatan şiirsel bir kıssa. İstanbul Boğazı'nda yer alan bu üç kanallı video yerleștirmesi, kendine başlangıç noktası olarak insanın seyyarlığının trajik bir imgesini alıyor: Büyük kentlerin yoksul bölgelerinde sıkça rastlanan türden, sular üzerinde geçici 
barınaklar oluşturmak için kullanılan tekne-ev karışımı bir yapı. Teknenin önüne oturmuş bir kadın, gözünü sudan hiç ayırmadan, önünde akıp giden manzarayı izlemektedir. Ev içi ve gündelik rutin görüntüleri, manzaraların, kıyıların ve kentlerin görüntülerine karışır. İzledikçe acı tatlı bir ironiyle anlarız ki filmde başta ayrıymış gibi görünen üç yer aslında birbiriyle bağlantılı gerçekliklerin farklı bakış açılarından temsilidir. Film, çöküşün çeşitli biçimlerinden bahsediyor: Evin sunduğu güvenliğin çöküşü, içerisi-dışarısı mimarisinin çöküşü. Evim Evim Güzel Evim, çoğumuzun hareket halinde ve bir keşmekeşin içinde olduğu, bizi etkilemeyecek kadar uzak görünen trajedilerin bile düşündüğümüzden daha yakın olduğu ve belki de tanımadığımız komşuların aslında hemen yanı başımızda bulunduğu tepetaklak ve tersyüz olmuş bir dünyayı derinlemesine yansitıyor (Lorios, 2017).

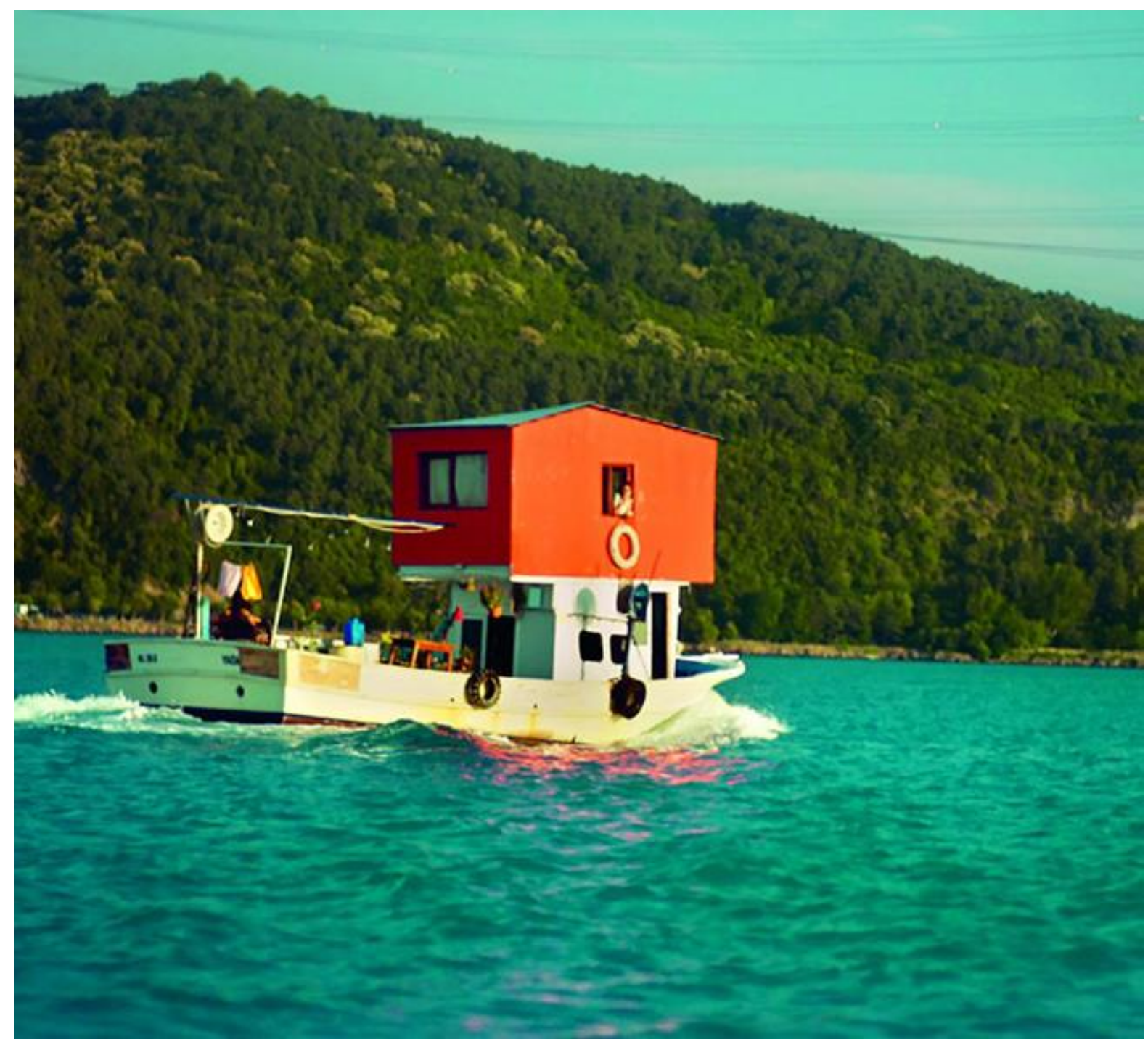

Görsel 6. Volkan Aslan, Evim Evim Güzel Evim, Üç kanallı video, 6'47”, 2017

Berlin'de yaşayan Gürcü sanatçı Vajiko Chachkhiani'nin yapıtları, çoğunlukla yaşayan şimdinin kendini geçmiş yaşamdan ve tarihten ayırıp ayırmadığını ya da nasıl ayırdığını sorguluyor. Yaşam Yolu isimli videosu (Görsel 7), insanın kapatılma koşulları altındaki varoluşunun bir portresidir. $\mathrm{Bu}$ kısa video, gözlem, etkinlik, entropi ve yaşlanmanın gergin diyalektiği üzerine yoğunlaşıyor. Kendimizi, ahşap çerçevesi çatlamış ve pul pul dökülmüş bir pencerenin karşısında buluyoruz. Bir süre sonra kadraja şişman sayılabilecek orta yaşlı bir adam giriyor, karanlık odanın içinde o da gözlerini dikmiş izleyiciye bakıyor. Neler olup bittiğini merak edercesine, ürkütücü bakışlarla pencereden dışarıya bakıyor; bakışlarında kararlı. Bizi mi gözetliyor? Yoksa biz mi onun dünyasına bakıyoruz? Bu bakış, bildik dostane bir ifade mi, yoksa bir toplumsal denetim aracı mı? Dışarıda doğa da varlığını hissettirmeye başlıyor: Kuş sesleri geliyor, bir baykuş ötüyor. Birkaç dakika sonra, bu 
1srarcı ve sessiz adam sonunda çekiliyor. Kadrajdan çıkmasıyla birlikte, doğanın sesleri ve ağaçların camdaki yansıması adamın görüntüsüne baskın geliyor.

Aynı anda hem sinir bozucu hem de dokunaklı olan bu video, insanın dirençliliğinin bir resmini sunmaktadır. Chachkhiani, videoyu ölmek üzere olan bakıma muhtaç hastaların bulunduğu bir düşkünlerevinin dışında çekmiştir. Video, kendi deyişiyle sadece hepimizin ölüme doğru yürümekte olduğunu hatırlatmaya çalışmıyor, aynı zamanda yaşama isteğimizi ve yaşama nasıl sıkı sıkıya tutunduğumuzu, içinde bulunduğumuz mevcut koşulların sürekli ötesine geçebilme gücümüzü gösteriyor. Videoda ancak belli belirsiz seçebildiğimiz gölgeler, toplumda gölgede kalanları, örneğin hastaları, engellileri ve yaşlıları, çoğunlukla kayıtsız olan bir toplumda görünmeyen ya da gözlerden saklanan marjinalleştirilmiş insanları akla getiriyor (Lorios, 2017).

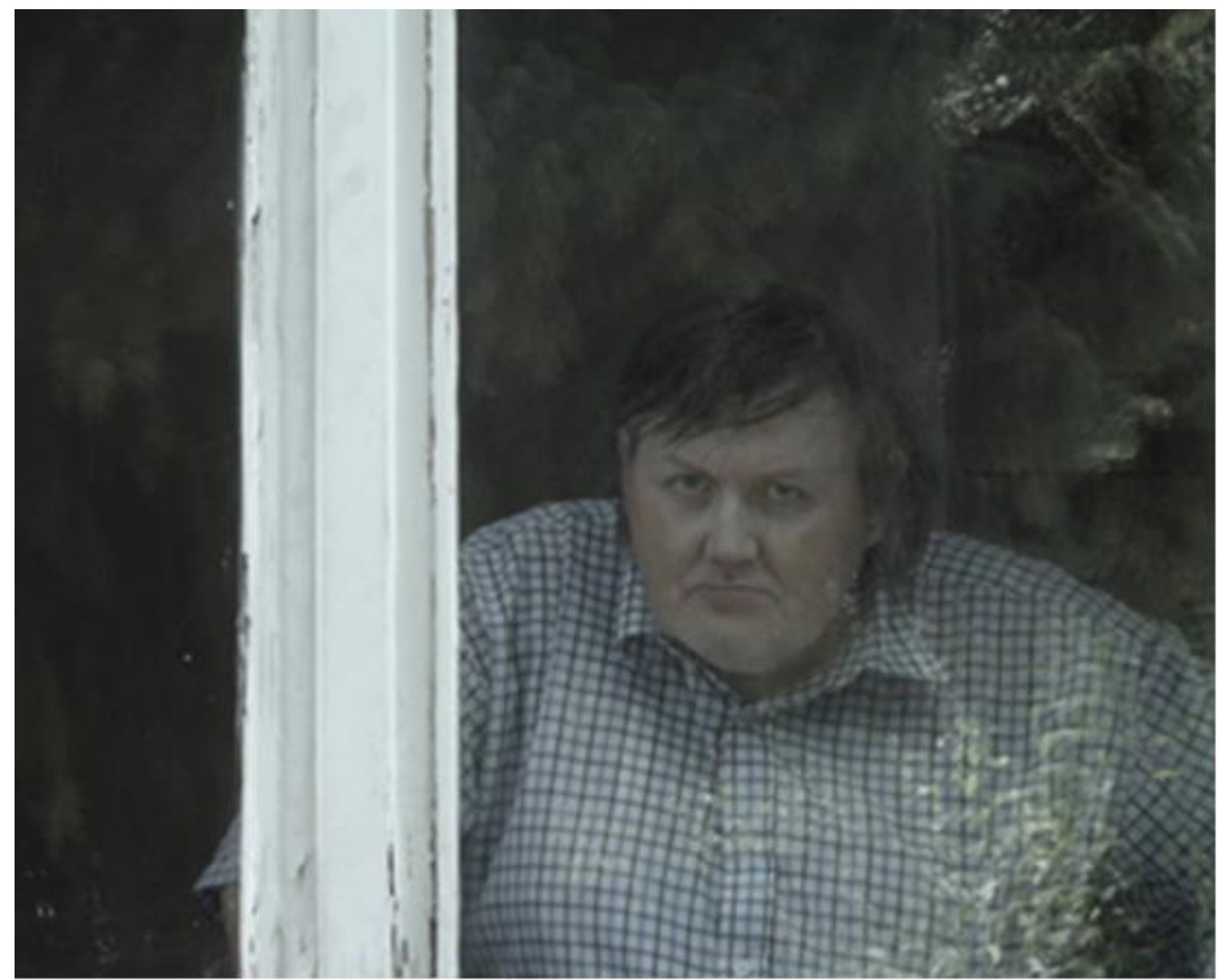

Görsel 7. Vajiko Chachkhiani, Yaşam Yolu, Tek kanallı HD video, ses 3'34”, 2015

Henrik Olesen'in yapıtları, bastırılmış olanın, görünmeyenin, gizlenmiş, özel ve dışlanmış olanın siyaseti üzerine incelemelerdir. Kolaj ya da yazıcı çıktısı gibi basit malzemelerle ya da bir kimsenin özel eşyalarını bir duvar üzerine yerleştirerek, özellikle de eşcinselliğin tarihiyle uyumlu bir şekilde, bireysel kimliğin nasıl tutsak edildiğini araştırır. Olesen'in İstanbul Bienali için ürettiği enstalasyonlar ve hayaletimsi kolajlar serisi, pis komşu figürüne ya da mahallenin nasıl da bir dikizcilik, güvensizlik, fetişizm ve tekinsizlik alanı haline gelebileceğine odaklanıyor. Serideki yapıtlar, -pek çok anlamıylakomşuların bize dostluk edebileceği gibi bizi pekâlâ korkutabileceği gerçeğinden yola çıkıyor. Etrafımızdaki insanlara bize ve sınırlarımıza saygı duyacakları konusunda güvendiğimiz için böyle yapmayabileceklerine dair korkularımız mahalleleri hasmane ve hatta tehlikeli yerlere dönüştürebilir. Kazara ya da röntgenci gibi -Alain Robbe-Grillet'nin Dikizci adlı romanında etraflıca ele aldığı mahalle arketipi- özel anlarımızda seyredildiğimiz ve bizim de başkalarını seyrettiğimiz komşuluk yaşamının böyle dikizcilik boyutu da vardır. Olesen İstanbul Bienali'ndeki yapıtında cinsel fantezi, 
dikizcilik ve ortak yaşamın çarpışması üzerine düşünüyor. İstanbul Modern'de yer alan mekâna özgü enstalasyonunda, izleyicilik, mahremiyet ve sınırları delme gibi meseleleri çağnışımsal bir tarzda ele alan bir dizi soyut kolaya yer veriyor. Henüz olgunlaşmamışlı̆̆ın acınası havasını taşıyan bu kolajlar, Georges Bataille'ın informe kavramı ile Adnan Çoker ve Fahrelnisa Zeid gibi Türkiyeli soyut ressamların yapıtlarını akla getiriyor. Saydam plastik ve aynadan yansitılan arka planlar üzerinde katmanlar oluşturmaya dayalı bir yöntemle üretilmiş olan kolajlarda, delik, anahtar, gözlük ya da kablo gibi mimari ve mekânsal ayrıntıların soyutlamaları sunuluyor. İzleme ya da izlenme etiği ve teknolojileri, toplumsal yakınlık ve uzaklık, bir arada yaşamanın gereği olarak girilen rasgele ve bazen de tekinsiz ilişkilerde yaşanan belirsizlik ve hatta cinsel fantezilerin flu gerçekliğine ilişkin sorular ortaya at1liyor (Lorios, 2017).

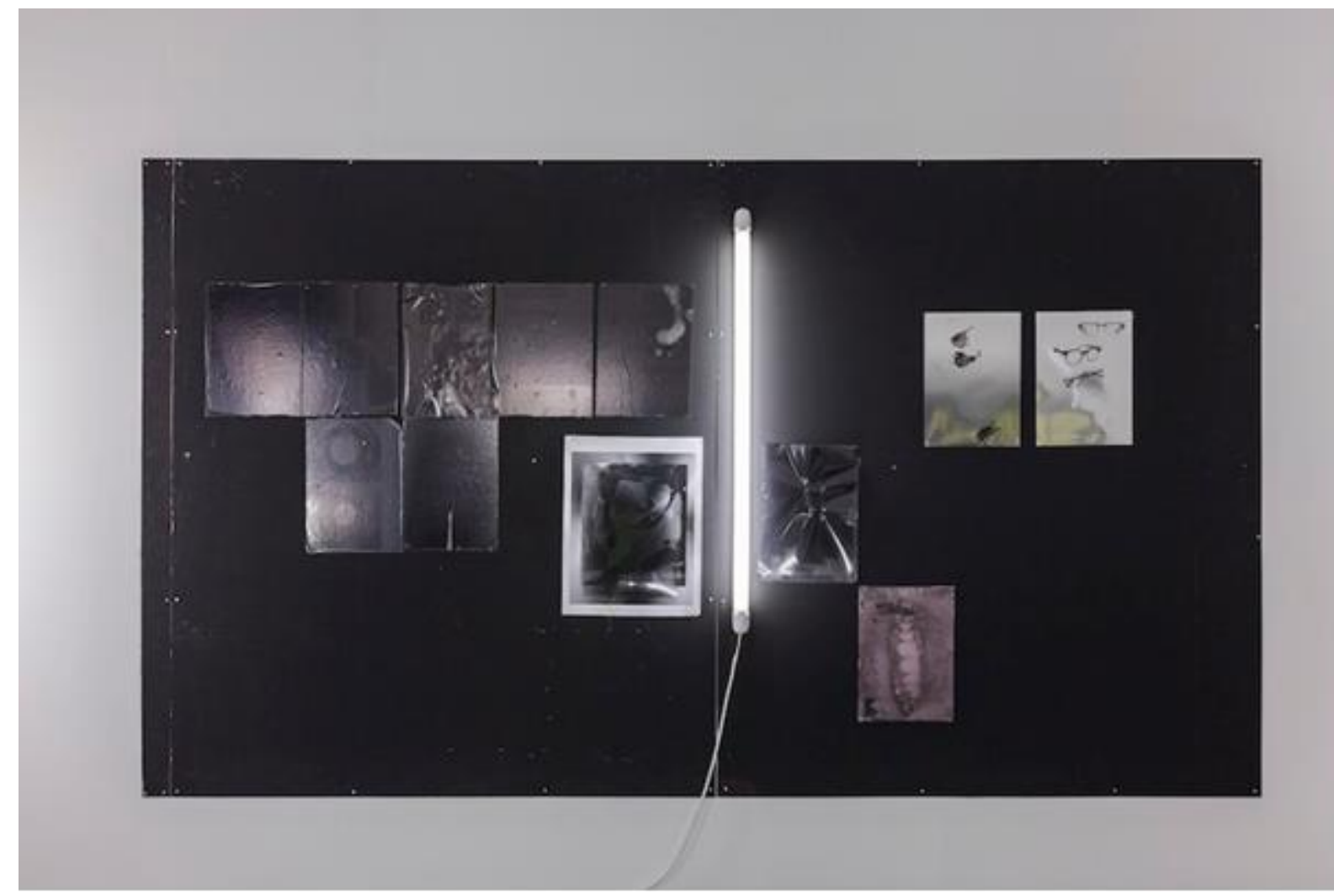

Görsel 8. Henrik Olesen, Kablolar-Anahtarlar-Gözlükler-Işıklar, Değişken boyutlar, Karışık medya enstalasyonu, 2017

\section{SONUÇ}

15. İstanbul Bienali bireyin kendisini, yaşantısını sorgulatan, bir an olsun duraklayıp çevre ile ilişki kurmasını sağlayan, izleyiciyi eski, kaybolmuş değerleriyle yeniden buluşturan, bazen masalsı, bazen ürkütücü, bazen tiksindirici çalışmalarla kamuoyunun karşısına çıkmıştır. Ev alma, komşu al, kötü komşu, insanı ev sahibi yapar, komşu komşunun külüne muhtaçtır gibi atasözlerinin çağrışımlarını barındıran bu bienal, bir tür zamanda yolculuğa kapı aralarken, güncel yaşam akışının betonlaşan, monotonlaşan, yabancılaşmış ve yalnızlaşmış hallerine dikkat çekmiştir. Modern çağın teknolojik girdabında kaybolmuş bireylerin sanal dünyada kurulan arkadaşlıkları tercih etmeye başladığından beri insan ontolojik yapısındaki birçok değeri yitirmiştir. 15. İstanbul Bienali, düzenlendiği süreçte içinde bulunulan toplumsal savaştan ve siyasi depremlerden sıyrılarak benliğimize inmeyi başarmıştır. Komşuluk ve yerellik kavramları üzerinden kurgulanan sergide gerçekleştirilen etkinliklerin ve üretimlerin, başlıkla olan ilişki düzeyinin frekansı ve efektifliği zaman zaman tartışılmış olsa da, temayla bir şekilde korelasyonu olan çalışmalar, bienalin bağlamını izleyiciye geçirmeyi başarmıştır. Tüm dünyada sınırların keskinleştiği, milliyetçi ve hatta ırkçı dalgaların yükseldiği, şiddet içeren her türlü tehdidin her an ve her yerde hissedildiği bir ortamda 15. İstanbul Bienali, bir arada durarak ve birbirimize dayanarak ayakta kalmaya yönelik parametreler geliştirmiştir. Bununla birlikte 2020 
yılının başından beri küresel ölçekte yaşanan covid-19 salgını sürecinde sosyal mesafelerin artması ve internetin insanları bir araya getirme aracına dönüşmesiyle birlikte sanal kamusal alanlar, bu kez sivil toplum özelinde yeni bir çerçeveden incelenmeye başlanmıştır. Bu dönemde 15. İstanbul Bienali'nin kavramsal çerçevesi yeni bir konuma oturmuş, bağlamı genişlemiştir. Evde kal çağrılarıyla birlikte geleneksel iletişim ve sosyalleşme yöntemlerinin değiştiği, ülkelerin sınırlarını kapatarak büyük ölçekli izolasyon süreçlerine girdiği, herkesin birbirini potansiyel virüs taşıyıcısı olarak gördüğü bir ortamda komşuluk ilişkileri de değişime uğramıştır. Bu sürecin biriktirdiği bellek, yaşanan deneyimler ve üretilen pratikler farklı sanatsal disiplinlerle geri dönüştürülebilir, özgür düşünce ve yaratıcılığın öne çıkacağı bir ifade sürecine olanak tanınabilirse iyi birer komşu olmanın, müşterek yaşamın en temel koşulu olduğu sanat aracılığıyla yeniden hatırlatılabilir. İsveçli coğrafya profesörü Torsten Hagerstrand'ın da ifade ettiği gibi, ancak komşu olmayı başarabilen gerçek anlamda hayatta kalabilir.

Bilgilendirme / Acknowledgement:

1- Makalemizde etik kurulu izni ve/veya yasal/özel izin alınmasını gerektiren bir durum yoktur.

2- Bu makalede araştırma ve yayın etiğine uyulmuştur.

\section{KAYNAKÇA}

Arapoğlu, F. (2017). 15. uluslararası İstanbul bienalinin ardından. Aurum Sosyal Bilimler Dergisi, 2(2), 69-75.

Bachelard, G. (1996). Mekânın poetikası. İstanbul: Kesit Yayıncılık.

Elmgreen ve Dragset. (2017). İyi bir komşu bienal kitabı (Sunuş). İstanbul: Yapı Kredi Yayınları.

Ersöz, E. (2009). Bienallerin anatomisi, Artist Actual Dergisi, Ekim, 26 - 27.

Lorios, P. (2017). İyi bir komşu bienal kitabı. İstanbul: Yapı Kredi Yayınları.

Okur, A. ve Bozdoğan, N. (2017). Türk sanat ortamı ve İstanbul bienalleri. İdil Sanat ve Dil Dergisi, $39,3305-3319$.

Örer, B. (2017). L̇yi bir komşu bienal kitabı (Önsöz). İstanbul: Yapı Kredi Yayınları.

Rosenblum, N.L. (2016). Good neighbors: the democracy of everyday life in America. Princeton: Princeton University Press.

Stallabrass, J. (2016). Sanat A.Ş. çağdaş sanat ve bienaller. İstanbul: İletişim Yayınları.

Stavrides, S. (2018). Müşterek mekân. İstanbul: Sel Yayıncılık.

Yardımcı, S. (2014). Küreselleşen İstanbul'da bienal. İstanbul: İletişim Yayınları.

\section{GÖRSEL KAYNAKÇA}

Görsel 1. 1 Nisan 2020 tarihinde http://www.diken.com.tr/iyi-bir-komsu-kimdir-9-soruda-15inciistanbul-bienali/ adresinden erişildi.

Görsel 2. 1 Nisan 2020 tarihinde http://www.birikimdergisi.com/guncel-yazilar/8533/15-istanbulbienali-uzerine-notlar\#.XDZ12lwzZPY adresinden erişildi.

Görsel 3. 1 Nisan 2020 tarihinde http://ensembles.mhka.be/events/collectiepresentatie-xviiiontmoeting?locale $=$ en adresinden erişildi. 
Görsel 4. 1 Nisan 2020 tarihinde https://www.artfulliving.com.tr/sanat/sonu-gelmeyecekmis-cikisyokmus-gibi-i-13571 adresinden erişildi.

Görsel 5. 1 Nisan 2020 tarihinde https://xoxodigital.com/post/11598/15-istanbul-bienalinde-ikinciduragimiz-galata-rum-okulu adresinden erişildi.

Görsel 6. 1 Nisan 2020 tarihinde http://15b.iksv.org/sanatcilar adresinden erişildi.

Görsel 7. 1 Nisan 2020 tarihinde http://www.mimarizm.com/haberler/gundem/bienal-notlari-3-peramuzesi_128732 adresinden erişildi.

Görsel 8. 1 Nisan 2020 tarihinde https://xoxodigital.com/post/11610/15-istanbul-bienalinde-sonduragimiz-istanbul-modern adresinden erişildi. 